\title{
Antioxidant Studies and GCMS Analysis of the Phytochemical Compounds of Some Endangered Plant Species Collected from the Western Ghats
}

\author{
N. Sumangala ${ }^{1^{*}}$, M. Jayaramu ${ }^{2}$ and M.P. Prasad ${ }^{3}$ \\ ${ }^{1}$ Microbiology, Tumkur University, Karnataka, India \\ ${ }^{2}$ Department of Studies and Research in Environmental Sciences, Tumkur University, \\ Karnataka, India \\ ${ }^{3}$ Sangene Biotech, Bengaluru, Karnataka, India
}

*Corresponding author

\begin{abstract}
A B S T R A C T
\section{Keywords}

Antioxidant, DPPH, Metal ion, Hydroxyl radical, Superoxide anion radical

Article Info

Accepted:

26 May 2019

Available Online:

10 June 2019

Plant has an innate ability to produce non-enzymatic antioxidants which have an important role in the metabolism of Reactive oxygen species (ROS). Several plants serve as the source of therapeutic agents but the properties depend on the plant nature. Thus, an evaluation of antioxidant activity is essential to determine the importance of a plant. Three plants Utleria salicifolia, Plectranthus vettiveroides and Nothapodytes nimmoniana were selected to carry out the antioxidant study. Methanol assisted leaves extracts were prepared and subjected to antioxidant assay by means of DPPH radical scavenging assay, Metal ion Chelating Assay, Superoxide Anion Radical Scavenging Assay and Hydroxyl radical scavenging assay. All the extracts showed 20-80\% inhibition depending on the concentration of extracts and the type of assay as well. The existence of crucial organic compounds in the leaf extracts of all the three plants were corroborated by Gas chromatography analysis. The present results offer supporting evidence for effective use of selected plant extracts.
\end{abstract}

\section{Introduction}

Free radicals play a crucial role in the development of tissue damage in pathological events. Antioxidants are chemical compounds which have the ability to quench the free radicals and thereby it prevents the human body against various diseases. Plants are the rich sources of antioxidants which contain secondary metabolites such as phenolic and flavonoid compounds commonly which act as antioxidants with redox and metal chelating properties (Karimi and Jaafar, 2011). Antioxidants are characterized as free radical which has an essential role to develop the damaged tissue in pathological field. Medicinal plants have been investigated from long time to evaluate their antioxidant properties. Natural antioxidants have potential to interrupt the destruction which is resulted from oxidative stress. These antioxidants may be either natural extracts or as an essential chemical compound of the extract (Zengin et al., 2011). Though medicinal plants have been 
carefully assessed for their toxicity profile, still the plant derived medicines are safer as compared to synthetic medicines (Vongtau et al., 2005; Oluyemi et al., 2007). The ROS and other oxidant result in disease and disorders as proved by different evidence. The evidence has brought the attention of scientists to an appreciation of antioxidants for prevention and treatment of diseases, and maintenance of human health (Halliwell et al., 1981). Human body has an inherent antioxidative mechanism and many of the biological functions such as the anti-mutagenic, anti-carcinogenic, and anti-aging responses originate from this property (Gulcin et al., 2012; Gocer et al., 2011). Antioxidants stabilize or deactivate free radicals, often before they attack targets in biological cells (Nunes et al., 2012) Recently interest in naturally occurring antioxidants has considerably increased for use in food, cosmetic and pharmaceutical products, because they possess multifacetedness in their multitude and magnitude of activity and provide enormous scope in correcting imbalance (Djeridane et al., 2006; Wannes et al., 2010).

It is well known that free radical reaction is actively involved in disease pathology resulting in several chronic and acute disease in human such as neurodegeneration, atherosclerosis, immunosuppression, aging and diabetes (Harman et al., 1998). If the balance between inherent antioxidant capacity of the body and ROS is disrupted then medicinal supplements and dietary are provided during attacked by disease. Several researches on vegetables, herbal plants and fruits specified the presence of antioxidants including flavonoids, phenolics, proanthocyanidins and tannins. Antioxidant from medicinal plants offers quite well protection against disease.

The ingestion of natural antioxidants has been inversely associated with morbidity and mortality from degenerative disorders (Gulcin et al., 2012). Liver diseases remain a serious health problem. Free radicals result in the damage of cell by covalent binding as well as lipid peroxidation. This further causes the injury to tissue. Antioxidant agents of natural origin have attracted special interest because of their free radical scavenging abilities (Osawa et al., 1990). The use of medicinal plants with high level of antioxidant constituents has been proposed as an effective therapeutic approach for hepatic damages (Govind et al., 2011).

Reactive oxygen species (ROS) and Reactive Nitrogen Species (RNS) are the products of normal cellular metabolism recognized for playing the either harmful or beneficial effect in living system. Increase in concentration of free radicals or decreased endogenous antioxidant mechanism can lead to oxidative stress which is responsible for the development of many degenerative diseases (Saikat et al., 2014).

GC-MS is an important technique to analyze the plant extract in order to determine the presence of essential herb compound which are often used in pharmaceutical, drug, cosmetic or food industry, environmental and forensic applications (Uma et al., 2009). This technique is the combination of two separate analytical methods to separate and determine the chemical components of a given mixture. Separation is done by Gas Chromatography whereas the components analysis is carried out by mass spectroscopy. Chemical studies have shown that it mainly contains cardenolides, pregnane glycosides and volatile components. Maximum volatile components belong to the class of long chain unsaturated fatty acids. These are the building elements of several valuable compounds and also an essential energy source. Due to these features, the volatile compounds play vital role in the biological system $(\mathrm{Mu}$ et 
al., 2001). In recent years, increasing research has been carried out on fatty acids and the results obtained show that they possess significant sedative and hypnotic effects (Zhang et al., 1995).

The current study was conducted to prepare the methanol extract of Utleria salicifolia, Plectranthus vettiveroides and Nothapodytes nimmoniana leaves. The extracts were assessed for their antioxidant activity. The content of the extracts were determined by Gas Chromatography - Mass Spectrometry analysis.

\section{Materials and Methods}

\section{Preparation of plant extract}

The plant samples were collected from the following locations, Utleri salicifolia, Curcuma zeodatia, Nothapodytes nimmoniana from the Western Ghats of Kerala. Plectranthus vettiveroides from Tamilnadu. Cayratia pedate from the Western Ghats bordering Kerala and Tamilnadu and Karnataka states. Rhaphidophora persuta from the Western Ghats of Karnataka and Syzygium travancoricum from fresh water Myristica swamps of Kerala and Uttar Kannada district of Karnataka.

Utleria salicifolia, Plectranthus vettiveroides and Nothapodytes nimmoniana leaves were selected to study antioxidant activity and GCMS analysis. The collected leaves were washed thoroughly with tap water followed by distilled water several times in order to remove the dust and soil particles.

The leaves were then shade dried and used for extraction. $100 \mathrm{gm}$ of all the three plant leaves powder were treated with methanol and extracted using soxhlet apparatus. The extract thus obtained was concentrated by evaporation in rotary vacuum evaporator.

\section{In-vitro Antioxidant Assay}

The antioxidant activity of the leaves extracts was carried out following four protocols.

\section{DPPH radical scavenging assay method}

$2.8 \mathrm{ml}$ of leaves extract $(20-100 \mu \mathrm{g} / \mathrm{ml})$ was mixed with $200 \mu \mathrm{L}$ of DPPH $(100 \mu \mathrm{M}$ in methanol) and incubated for $20 \mathrm{~min}$ in dark condition. Absorbance was taken at $517 \mathrm{~nm}$. A mixture of DPPH and methanol was used as control. Ascorbic acid was taken as reference standard. Percentage of DPPH inhibition was determined according to Prasad (2015).

$$
\begin{aligned}
& \text { (Absorbance of control - Absorbance of test) } \\
& \times 100 \\
& \text { Inhibition }(\%)=\text {---------------------...Eq } 1
\end{aligned}
$$

\section{Metal ion chelating assay}

This assay was carried out by determining the chelating potential of $\mathrm{Fe}$ ion present in the extract. 2,2'-bipyridyl competition assay was conducted by mixing $0.25 \mathrm{~mL}(1 \mathrm{mM}) \mathrm{FeSO}_{4}$ solution to the equal volume of concentrated extract $(200-1000 \mu \mathrm{g} / \mathrm{ml})$. To this mixture $1 \mathrm{~mL}$ Tris $\mathrm{HCl}$ buffer $(\mathrm{pH} 7.4)$ and $0.25 \mathrm{~mL}$ (0.1\%) 2,2'-bipyridyl solution were added along with $0.4 \mathrm{~mL}$ hydroxylaminehydro chloride and $2.5 \mathrm{~mL}$ ethanol. Final volume of the solution was adjusted to $5 \mathrm{ml}$ by distilled water. The resulting solution was incubated at room temperature for 10 minutes. The absorbance was taken at $522 \mathrm{~nm}$ with EDTA as reference chelating agent. The $\mathrm{Fe}^{2+}$ chelating activity of the extract was determined as per the following equation.

$$
\begin{aligned}
& \text { (Absorbance of control - Absorbance of test) } \\
& \times 100 \\
& \text { Inhibition }(\%)=\text {----------------------------...Eq } 2 \\
& \text { Absorbance of control }
\end{aligned}
$$




\section{Superoxide anion radical scavenging assay}

NBT reduction method was adopted to assess superoxide anion radical scavenging activity. $0.1 \mathrm{ml}$ concentrated plant extract (200-1000 $\mu \mathrm{g} / \mathrm{ml}$ ) was mixed with $1 \mathrm{~mL}$ NBT (in phosphate buffer $\mathrm{pH} 7.4$ ) and $1 \mathrm{~mL}$ of $\mathrm{NADH}$ solution. $100 \mu \mathrm{L}(60 \mu \mathrm{M})$ PMS was added to initiate the reaction and the reaction mixture was incubated for $15 \mathrm{~min}$ at $30^{\circ} \mathrm{C}$. The absorbance was measured at $560 \mathrm{~nm}$ with ascorbic acid as reference standard. The inhibition percentage was calculated by the following equation.

(Absorbance of control - Absorbance of test)

$$
\text { Inhibition }(\%)=\frac{\times 100}{\text { Absorbance of control }}
$$

\section{Hydroxyl radical scavenging assay}

Hydroxyl radical scavenging activity of the plant extract was determined using 2-deoxy2- 3+ ribose oxidative degradation in $\mathrm{Fe}$ EDTA- 15 Ascorbate-H O system method. $3.5 \mathrm{ml}$ leaves extract was mixed with $28 \mathrm{mM}$ 2-deoxy-2-ribose, $1.04 \mathrm{mM}$ EDTA and $1 \mathrm{mM}$ ascorbic acid. The resulting solution was incubated for $1 \mathrm{hr}$ at $37^{\circ} \mathrm{C}$. The preventive effects of extract on deoxyribose damage, imposed by hydroxyl radicals were determined spectrophotometrically at $532 \mathrm{~nm}$ against blank for each concentration. Mannitol was taken as the reference. The inhibition percentage was calculated as:

(Absorbance of control - Absorbance of test)

$$
\text { Inhibition }(\%)=\frac{\times 100}{\text { Absorbance of control }}
$$

\section{GC-MS analysis of the leaf's extracts}

The GC-MS was run with a column oven temperature of $60^{\circ} \mathrm{c}$ and injection temperature of $250^{\circ} \mathrm{C}$ with split mode of injection and liner velocity flow control. The pressure applied for GC is $57.4 \mathrm{kpa}$ which gives the column flow of $1.00 \mathrm{ml} / \mathrm{min}$ and linear velocity of $36.5 \mathrm{~cm} / \mathrm{sec}$, with a purge flow of $3.0 \mathrm{ml} / \mathrm{min}$ and split ratio is 10.0 . The ion source temperature was set at $200^{\circ} \mathrm{C}$ and the interface temperature is $300^{\circ} \mathrm{C}$, with $2.00 \mathrm{~min}$ of solvent cut time. The Mass Spectra was taken with intervals of $0.50 \mathrm{sec}$, with a scan range of $40-600 \mathrm{~m} / \mathrm{z}$ with a scan speed of 1250. The total time taken is $34.00 \mathrm{~min}$ and FTD detector is used for detection.

\section{Results and Discussion}

\section{Antioxidant activity of Nothapodytes nimmoniana extract}

Table 1 and Figure 1 exhibited the DPPH radical scavenging capabilities of Nothapodytes nimmoniana leaf and ascorbic acid as well. As a standard ascorbic acid showed higher inhibition percentage as compared to leaves extract.

Inhibition percentage enhances with an increase in leaf extract concentration and a maximum $75 \%$ inhibition was observed at $100 \mu \mathrm{g} / \mathrm{ml}$ leaf extract concentration. For ascorbic acid inhibition became constant from 60 to $100 \mu \mathrm{g} / \mathrm{ml}$ concentration.

Metal ion chelating activity of leaf extract was compared to EDTA in Table 2 and Figure 2. Inhibition became constant at $35 \%$ at leaf extract concentration of 60 to $100 \%$ whereas inhibition increases with increase in EDTA content.

Assessment of Superoxide radical scavenging of leaf extract was depicted in Table 3 and Figure 3. Maximum 30\% inhibition was observed at $60 \mu \mathrm{g} / \mathrm{ml}$ leaf extract whereas $45 \%$ inhibition was obtained at $60 \mu \mathrm{g} / \mathrm{ml}$ ascorbic acid content. 
Hydroxyl radical scavenging assessment of leaf extract was exhibited in table 4 and Figure 4. Maximum 25\% inhibition was achieved at $60 \mu \mathrm{g} / \mathrm{ml}$ leaf extract. Further increase in extract concentration did not affect the inhibition percentage. $60 \mu \mathrm{g} / \mathrm{ml}$ mannitol showed $45 \%$ inhibition which was the maximum.

\section{Antioxidant activity of Utleria salicifolia extract}

The study carried out on the antioxidant activity of the methanol extract from the leaves of Utleria salicifolia using DPPH radical, metal chelating, hydroxyl and super oxide radical scavenging assays was described.

Table 5 and Figure 5 exhibits the DPPH radical scavenging capabilities of Utleria salicifolia leaf extract and ascorbic acid as well. As a standard ascorbic acid showed higher inhibition percentage as compared to leaves extract. Inhibition percentage enhances with an increase in leaf extract concentration up to $80 \mu \mathrm{g} / \mathrm{ml}$ and a maximum $45 \%$ inhibition was observed at this concentration.

For ascorbic acid inhibition became constant from 60 to $100 \mu \mathrm{g} / \mathrm{ml}$ concentration.

Metal ion chelating activity of leaf extract was compared to EDTA in Table 6 and Figure 6. Inhibition became constant at $50 \%$ at leaf extract concentration of 80 to $100 \%$ whereas inhibition increases with increase in EDTA content.

Assessment of Superoxide radical scavenging of leaf extract was depicted in Table 7 and Figure 7. Maximum 30\% inhibition was observed at $60 \mu \mathrm{g} / \mathrm{ml}$ leaf extract whereas $45 \%$ inhibition was obtained at $60 \mu \mathrm{g} / \mathrm{ml}$ ascorbic acid content.

Table.1 Variation of inhibition percentage with respect to the concentration of leaf extract and ascorbic acid

\begin{tabular}{|l|c|c|c|}
\hline $\begin{array}{l}\text { Concentration of leaf } \\
\text { extract }(\boldsymbol{\mu g} / \mathbf{m l})\end{array}$ & $\begin{array}{c}\text { \% of } \\
\text { inhibitions }\end{array}$ & $\begin{array}{c}\text { Concentration of } \\
\text { ascorbic acid }(\boldsymbol{\mu g} / \mathbf{m l})\end{array}$ & $\begin{array}{c}\% \text { of } \\
\text { inhibitions }\end{array}$ \\
\hline $\mathbf{2 0}$ & 40 & 20 & 60 \\
\hline $\mathbf{4 0}$ & 50 & 40 & 80 \\
\hline $\mathbf{6 0}$ & 60 & 60 & 85 \\
\hline $\mathbf{8 0}$ & 70 & 80 & 85 \\
\hline $\mathbf{1 0 0}$ & 75 & 100 & 85 \\
\hline
\end{tabular}

Table.2 Metal ion chelation activity Assay of methanol extract of Nothapodytes nimmoniana leaves and standard EDTA

\begin{tabular}{|l|c|c|c|}
\hline $\begin{array}{l}\text { Concentration of leaf } \\
\text { extract }(\boldsymbol{\mu g} / \mathbf{m l})\end{array}$ & $\begin{array}{c}\text { \% of } \\
\text { inhibitions }\end{array}$ & $\begin{array}{c}\text { Concentration of EDTA } \\
(\boldsymbol{\mu g} / \mathbf{m l})\end{array}$ & $\begin{array}{c}\text { \% of } \\
\text { inhibitions }\end{array}$ \\
\hline $\mathbf{2 0}$ & 20 & 20 & 50 \\
\hline $\mathbf{4 0}$ & 30 & 40 & 55 \\
\hline $\mathbf{6 0}$ & 35 & 60 & 60 \\
\hline $\mathbf{8 0}$ & 35 & 80 & 65 \\
\hline $\mathbf{1 0 0}$ & 35 & 100 & 70 \\
\hline
\end{tabular}


Table.3 Superoxide radical scavenging assay of methanol extract of Nothapodytes nimmoniana leaves and standard Ascorbic acid

\begin{tabular}{|l|c|c|c|}
\hline $\begin{array}{l}\text { Concentration of leaf } \\
\text { extract }(\boldsymbol{\mu g} / \mathbf{m l})\end{array}$ & $\begin{array}{c}\text { \% of } \\
\text { inhibitions }\end{array}$ & $\begin{array}{c}\text { Concentration of } \\
\text { Ascorbic acid }(\boldsymbol{\mu g} / \mathbf{m l})\end{array}$ & $\begin{array}{c}\text { \% of } \\
\text { inhibitions }\end{array}$ \\
\hline $\mathbf{2 0}$ & 20 & 20 & 30 \\
\hline $\mathbf{4 0}$ & 25 & 40 & 40 \\
\hline $\mathbf{6 0}$ & 30 & 60 & 45 \\
\hline $\mathbf{8 0}$ & 30 & 80 & 45 \\
\hline $\mathbf{1 0 0}$ & 30 & 100 & 45 \\
\hline
\end{tabular}

Table.4 Hydroxyl radical scavenging assay of methanol extract of Nothapodytes nimmoniana leaves and standard Mannitol

\begin{tabular}{|l|c|c|c|}
\hline $\begin{array}{l}\text { Concentration of leaf } \\
\text { extract }(\boldsymbol{\mu g} / \mathbf{m l})\end{array}$ & $\begin{array}{c}\text { \% of } \\
\text { inhibitions }\end{array}$ & $\begin{array}{c}\text { Concentration of } \\
\text { Mannitol }(\boldsymbol{\mu g} / \mathbf{m l})\end{array}$ & $\begin{array}{c}\text { \% of } \\
\text { inhibitions }\end{array}$ \\
\hline $\mathbf{2 0}$ & 10 & 20 & 30 \\
\hline $\mathbf{4 0}$ & 20 & 40 & 40 \\
\hline $\mathbf{6 0}$ & 25 & 60 & 45 \\
\hline $\mathbf{8 0}$ & 25 & 80 & 45 \\
\hline $\mathbf{1 0 0}$ & 25 & 100 & 45 \\
\hline
\end{tabular}

Table.5 DPPH radical scavenging capabilities of methanol extract of Utleria salicifolia leaves and standard ascorbic acid

\begin{tabular}{|l|c|c|c|}
\hline $\begin{array}{l}\text { Concentration of leaf } \\
\text { extract }(\boldsymbol{\mu m} / \mathbf{m l})\end{array}$ & $\begin{array}{c}\text { \% of } \\
\text { inhibitions }\end{array}$ & $\begin{array}{c}\text { Concentration of } \\
\text { Ascorbic acid }(\boldsymbol{\mu m} \mathbf{m} \mathbf{m})\end{array}$ & $\begin{array}{c}\% \text { of } \\
\text { inhibitions }\end{array}$ \\
\hline $\mathbf{2 0}$ & 20 & 20 & 60 \\
\hline $\mathbf{4 0}$ & 30 & 40 & 80 \\
\hline $\mathbf{6 0}$ & 40 & 60 & 85 \\
\hline $\mathbf{8 0}$ & 45 & 80 & 85 \\
\hline $\mathbf{1 0 0}$ & 45 & 100 & 85 \\
\hline
\end{tabular}

Table.6 Metal ion chelation activity Assay of methanol extract of Utleria salicifolia leaves and standard EDTA

\begin{tabular}{|l|c|c|c|}
\hline $\begin{array}{l}\text { Concentration of leaf } \\
\text { extract }(\boldsymbol{\mu m} / \mathbf{m l})\end{array}$ & $\begin{array}{c}\text { \% of } \\
\text { inhibitions }\end{array}$ & $\begin{array}{c}\text { Concentration of EDTA } \\
(\boldsymbol{\mu m} / \mathbf{m l})\end{array}$ & $\begin{array}{c}\% \text { of } \\
\text { inhibitions }\end{array}$ \\
\hline $\mathbf{2 0}$ & 25 & 20 & 50 \\
\hline $\mathbf{4 0}$ & 30 & 40 & 55 \\
\hline $\mathbf{6 0}$ & 40 & 60 & 60 \\
\hline $\mathbf{8 0}$ & 50 & 80 & 65 \\
\hline $\mathbf{1 0 0}$ & 50 & 100 & 70 \\
\hline
\end{tabular}


Table.7 Superoxide radical scavenging assay of methanol extract of Utleria salicifolia leaves and standard Ascorbic acid

\begin{tabular}{|l|c|c|c|}
\hline $\begin{array}{l}\text { Concentration of leaf } \\
\text { extract }(\boldsymbol{\mu m} / \mathbf{m l})\end{array}$ & $\begin{array}{c}\text { \% of } \\
\text { inhibitions }\end{array}$ & $\begin{array}{c}\text { Concentration of } \\
\text { Ascorbic acid }(\boldsymbol{\mu m} / \mathbf{m l})\end{array}$ & $\begin{array}{c}\text { \% of } \\
\text { inhibitions }\end{array}$ \\
\hline $\mathbf{2 0}$ & 20 & 20 & 30 \\
\hline $\mathbf{4 0}$ & 25 & 40 & 40 \\
\hline $\mathbf{6 0}$ & 30 & 60 & 45 \\
\hline $\mathbf{8 0}$ & 30 & 80 & 45 \\
\hline $\mathbf{1 0 0}$ & 30 & 100 & 45 \\
\hline
\end{tabular}

Table.8 Hydroxyl radical scavenging assay of methanol extract of Utleria salicifolia leaves and standard Mannitol

\begin{tabular}{|l|c|c|c|}
\hline $\begin{array}{l}\text { Concentration of leaf } \\
\text { extract }(\boldsymbol{\mu m} / \mathbf{m l})\end{array}$ & $\begin{array}{c}\text { \% of } \\
\text { inhibitions }\end{array}$ & $\begin{array}{c}\text { Concentration of } \\
\text { Mannitol }(\boldsymbol{\mu m} / \mathbf{m l})\end{array}$ & $\begin{array}{c}\text { \% of } \\
\text { inhibitions }\end{array}$ \\
\hline $\mathbf{2 0}$ & 25 & 20 & 30 \\
\hline $\mathbf{4 0}$ & 35 & 40 & 40 \\
\hline $\mathbf{6 0}$ & 35 & 60 & 45 \\
\hline $\mathbf{8 0}$ & 35 & 80 & 45 \\
\hline $\mathbf{1 0 0}$ & 35 & 100 & 45 \\
\hline
\end{tabular}

Table.9 DPPH radical scavenging assay of methanol extract of Plectranthus vettiveroides leaves and standard Ascorbic acid

\begin{tabular}{|l|c|c|c|}
\hline $\begin{array}{l}\text { Concentration of leaf } \\
\text { extract }(\boldsymbol{\mu m} / \mathbf{m l})\end{array}$ & $\begin{array}{c}\% \text { of } \\
\text { inhibitions }\end{array}$ & $\begin{array}{c}\text { Concentration of } \\
\text { Ascorbic acid }(\boldsymbol{\mu m} / \mathbf{m l})\end{array}$ & $\begin{array}{c}\% \text { of } \\
\text { inhibitions }\end{array}$ \\
\hline $\mathbf{2 0}$ & 50 & 20 & 60 \\
\hline $\mathbf{4 0}$ & 60 & 40 & 80 \\
\hline $\mathbf{6 0}$ & 70 & 60 & 85 \\
\hline $\mathbf{8 0}$ & 80 & 80 & 85 \\
\hline $\mathbf{1 0 0}$ & 85 & 100 & 85 \\
\hline
\end{tabular}

Table.10 Metal ion chelation activity Assay of methanol extract of Plectranthus vettiveroides leaves and standard EDTA

\begin{tabular}{|l|c|c|c|}
\hline $\begin{array}{l}\text { Concentration of leaf } \\
\text { extract }(\boldsymbol{\mu m} / \mathbf{m l})\end{array}$ & $\begin{array}{c}\text { \% of } \\
\text { inhibitions }\end{array}$ & $\begin{array}{c}\text { Concentration of EDTA } \\
(\boldsymbol{\mu m} / \mathbf{m l})\end{array}$ & $\begin{array}{c}\text { \% of } \\
\text { inhibitions }\end{array}$ \\
\hline $\mathbf{2 0}$ & 25 & 20 & 50 \\
\hline $\mathbf{4 0}$ & 25 & 40 & 55 \\
\hline $\mathbf{6 0}$ & 25 & 60 & 60 \\
\hline $\mathbf{8 0}$ & 25 & 80 & 65 \\
\hline $\mathbf{1 0 0}$ & 25 & 100 & 70 \\
\hline
\end{tabular}


Table.11 Superoxide radical scavenging assay of methanol extract of Plectranthus vettiveroides leaves and standard Ascorbic acid

\begin{tabular}{|l|c|c|c|}
\hline $\begin{array}{l}\text { Concentration of leaf } \\
\text { extract }(\boldsymbol{\mu m} / \mathbf{m l})\end{array}$ & $\begin{array}{c}\text { \% of } \\
\text { inhibitions }\end{array}$ & $\begin{array}{c}\text { Concentration of } \\
\text { Ascorbic acid }(\boldsymbol{\mu m} / \mathbf{m l})\end{array}$ & $\begin{array}{c}\text { \% of } \\
\text { inhibitions }\end{array}$ \\
\hline $\mathbf{2 0}$ & 30 & 20 & 30 \\
\hline $\mathbf{4 0}$ & 40 & 40 & 40 \\
\hline $\mathbf{6 0}$ & 40 & 60 & 45 \\
\hline $\mathbf{8 0}$ & 40 & 80 & 45 \\
\hline $\mathbf{1 0 0}$ & 40 & 100 & 45 \\
\hline
\end{tabular}

Table.12 Hydroxyl radical scavenging assay of methanol extract of Plectranthus vettiveroides leaves and standard Mannitol

\begin{tabular}{|l|c|c|c|}
\hline $\begin{array}{l}\text { Concentration of leaf } \\
\text { extract }(\boldsymbol{\mu m} / \mathbf{m l})\end{array}$ & $\begin{array}{c}\text { \% of } \\
\text { inhibitions }\end{array}$ & $\begin{array}{c}\text { Concentration of } \\
\text { Mannitol }(\boldsymbol{\mu m} / \mathbf{m l})\end{array}$ & $\begin{array}{c}\text { \% of } \\
\text { inhibitions }\end{array}$ \\
\hline $\mathbf{2 0}$ & 10 & 20 & 30 \\
\hline $\mathbf{4 0}$ & 20 & 40 & 40 \\
\hline $\mathbf{6 0}$ & 20 & 60 & 45 \\
\hline $\mathbf{8 0}$ & 20 & 80 & 45 \\
\hline $\mathbf{1 0 0}$ & 20 & 100 & 45 \\
\hline
\end{tabular}

Fig.1 DPPH radical scavenging capabilities of methanol extract of Nothapodytes nimmoniana leaves and standard ascorbic acid

\section{DPPH radical scavenging capabilities}

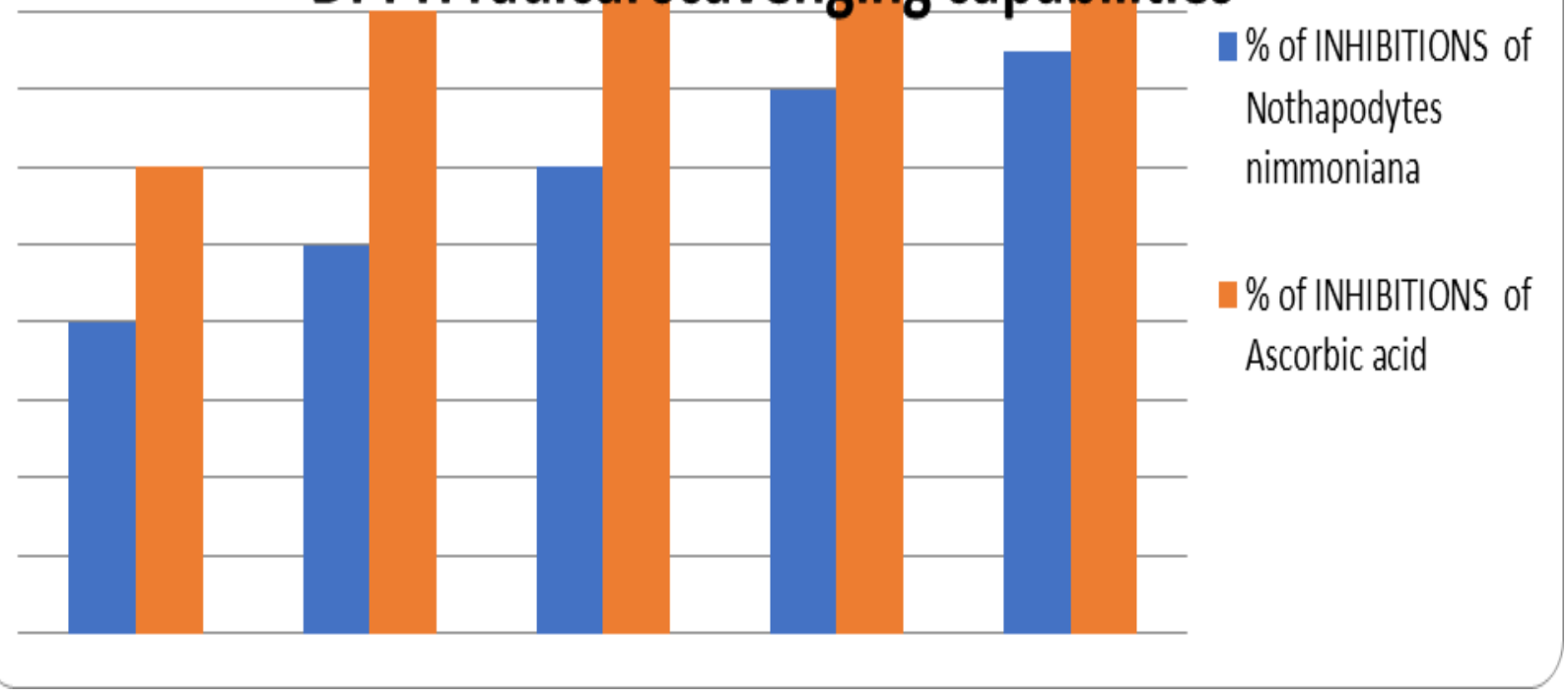


Fig.2 Metal ion chelating capabilities of methanol extract of Nothapodytes nimmoniana leaves and EDTA

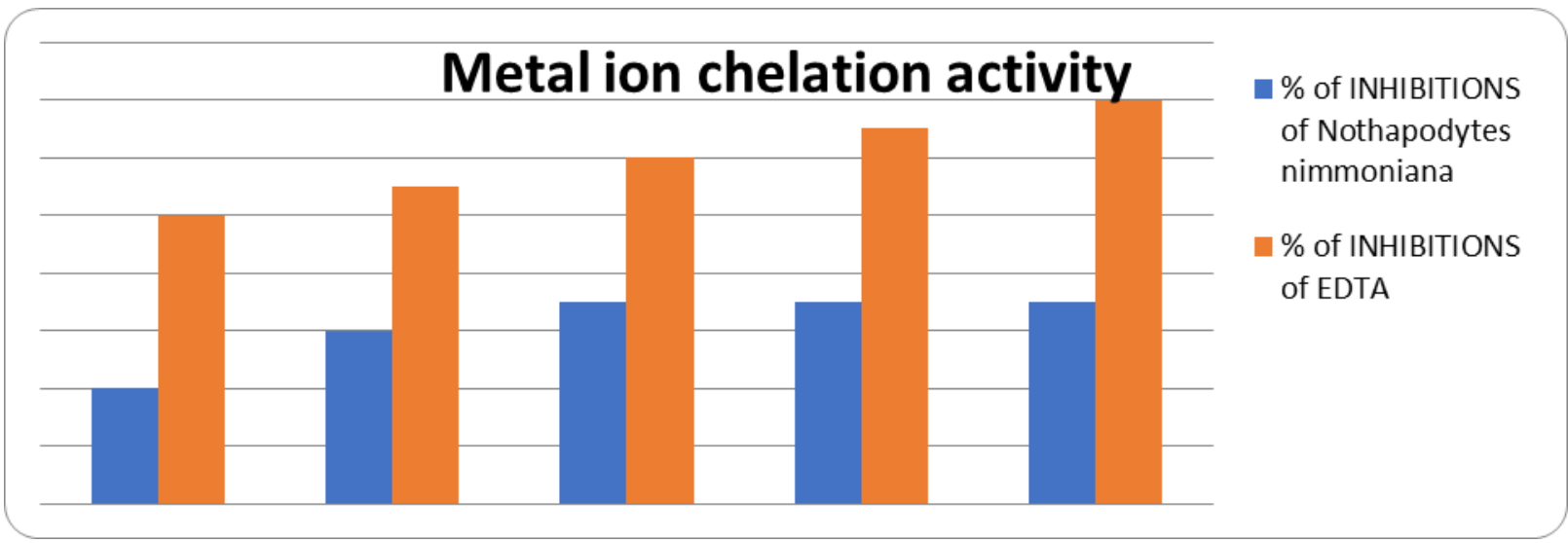

Fig.3 Superoxide ion radical scavenging capabilities of methanol extract of Nothapodytes nimmoniana leaves and Ascorbic acid.

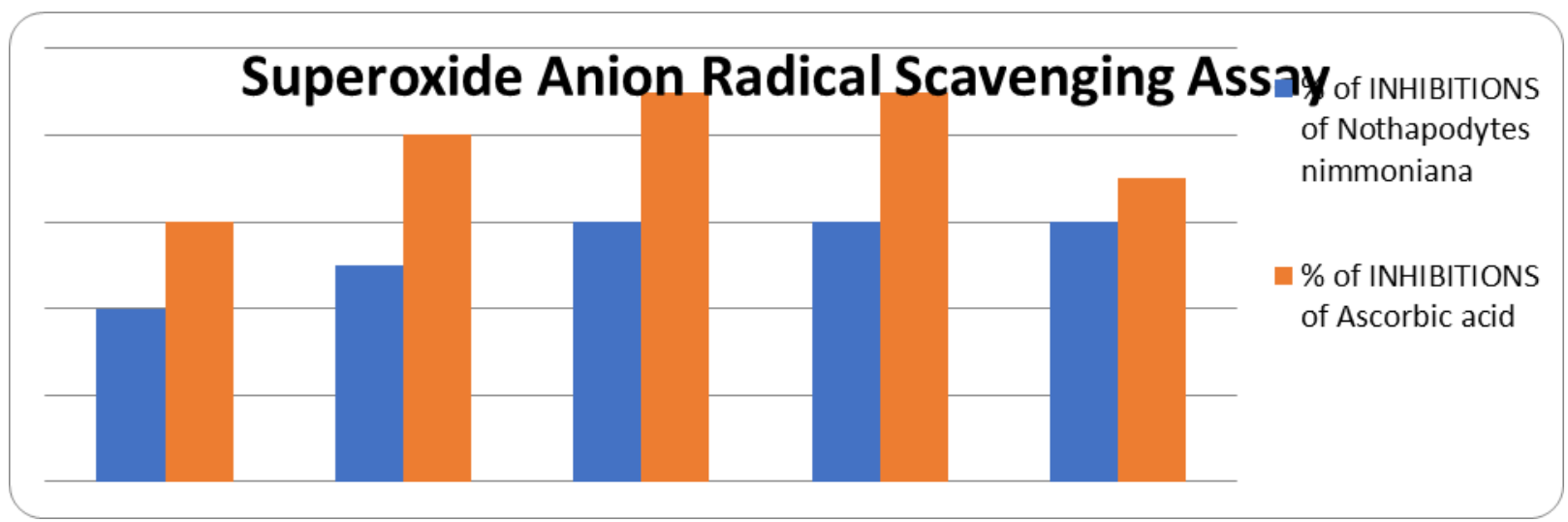

Fig.4 Hydroxyl radical scavenging capabilities of methanol extract of Nothapodytes nimmoniana leaves and Mannitol

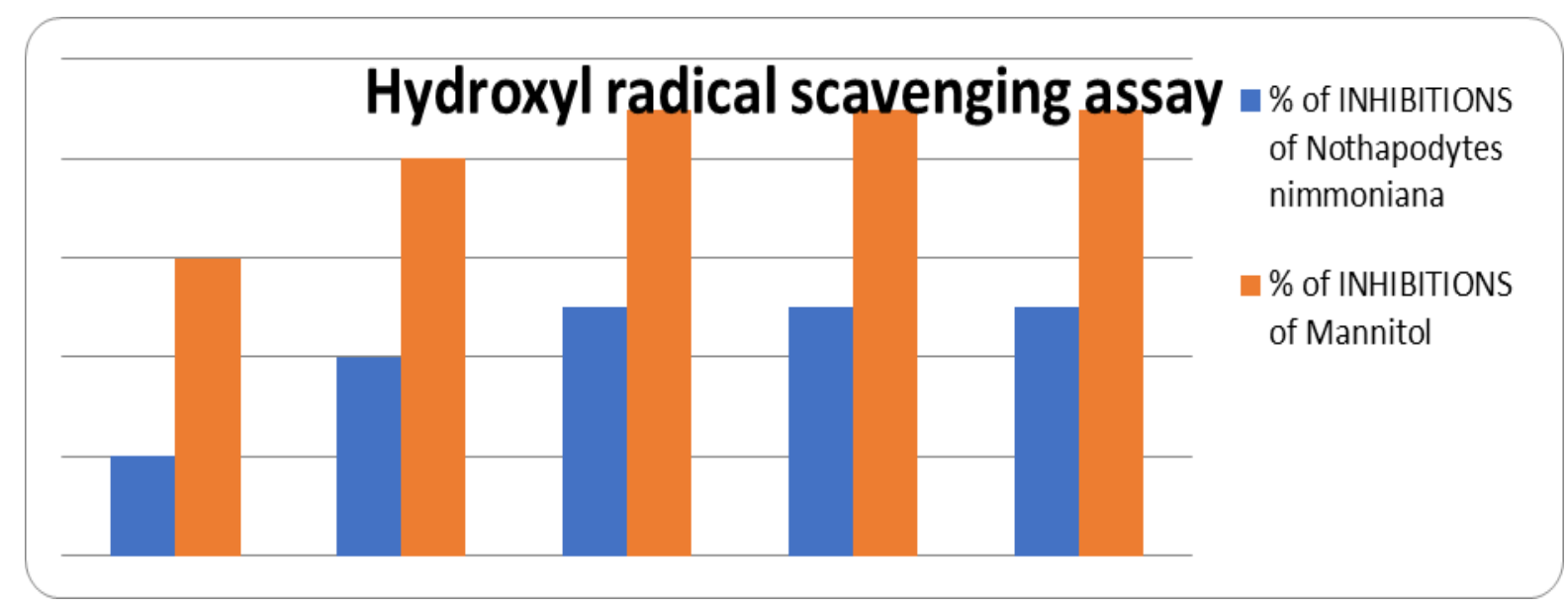


Fig.5 DPPH radical scavenging capabilities of methanol extract of Utleria salicifolia leaves and standard ascorbic acid

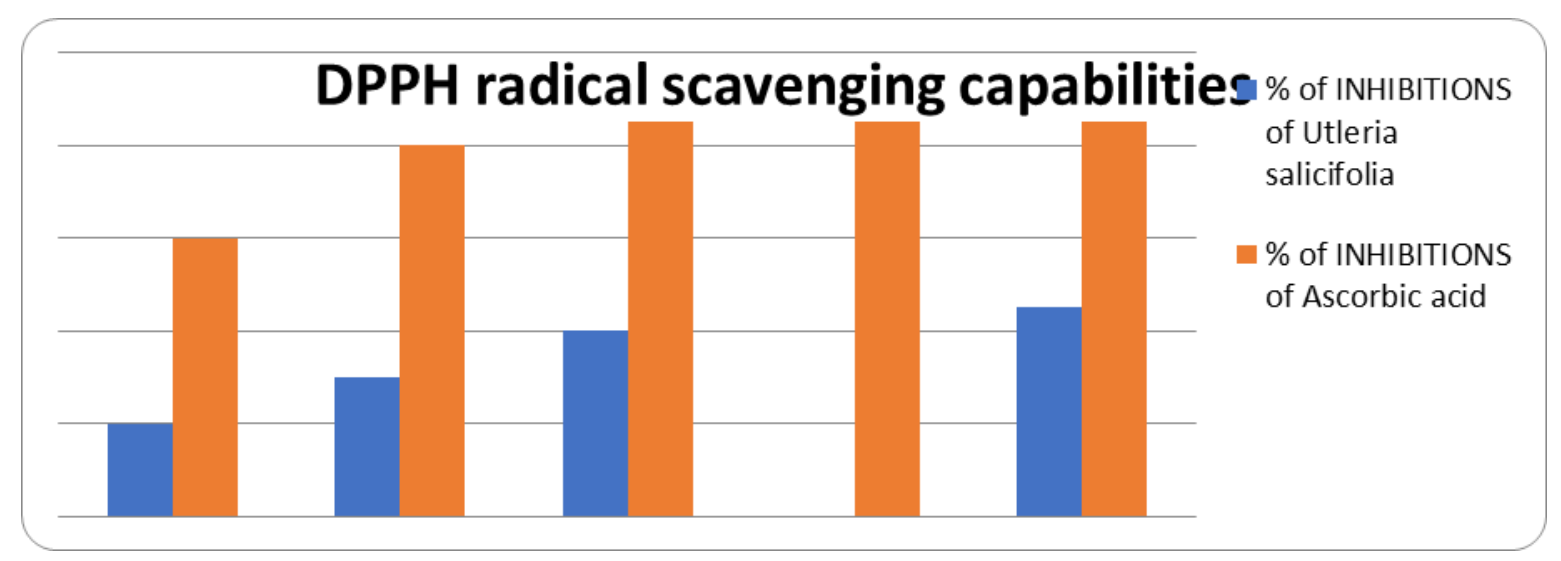

Fig.6 Metal ion chelating capabilities of methanol extract of Utleria salicifolia leaves and EDTA

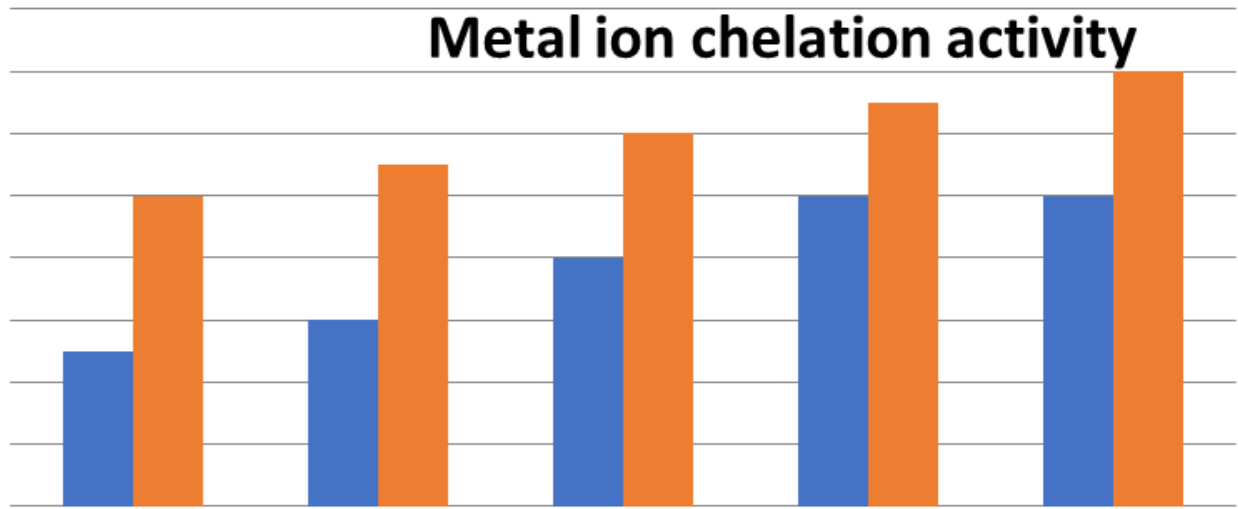

\% of INHIBITIONS

of Utleria

salicifolia

\% of INHIBITIONS

of EDTA

Fig.7 Superoxide radical scavenging capabilities of methanol extract of Utleria salicifolia leaves and Ascorbic acid

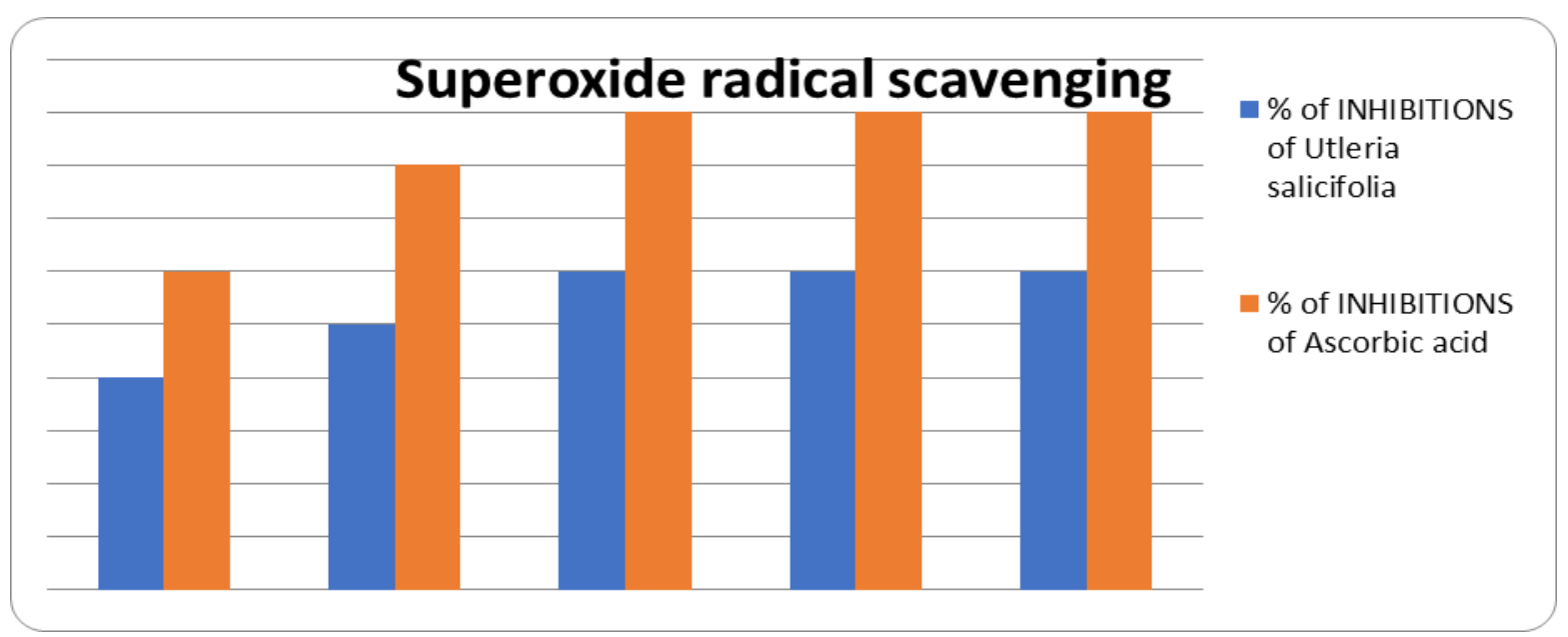


Fig.8 Hydroxyl radical scavenging capabilities of methanol extract of Utleria salicifolia leaves and Mannitol

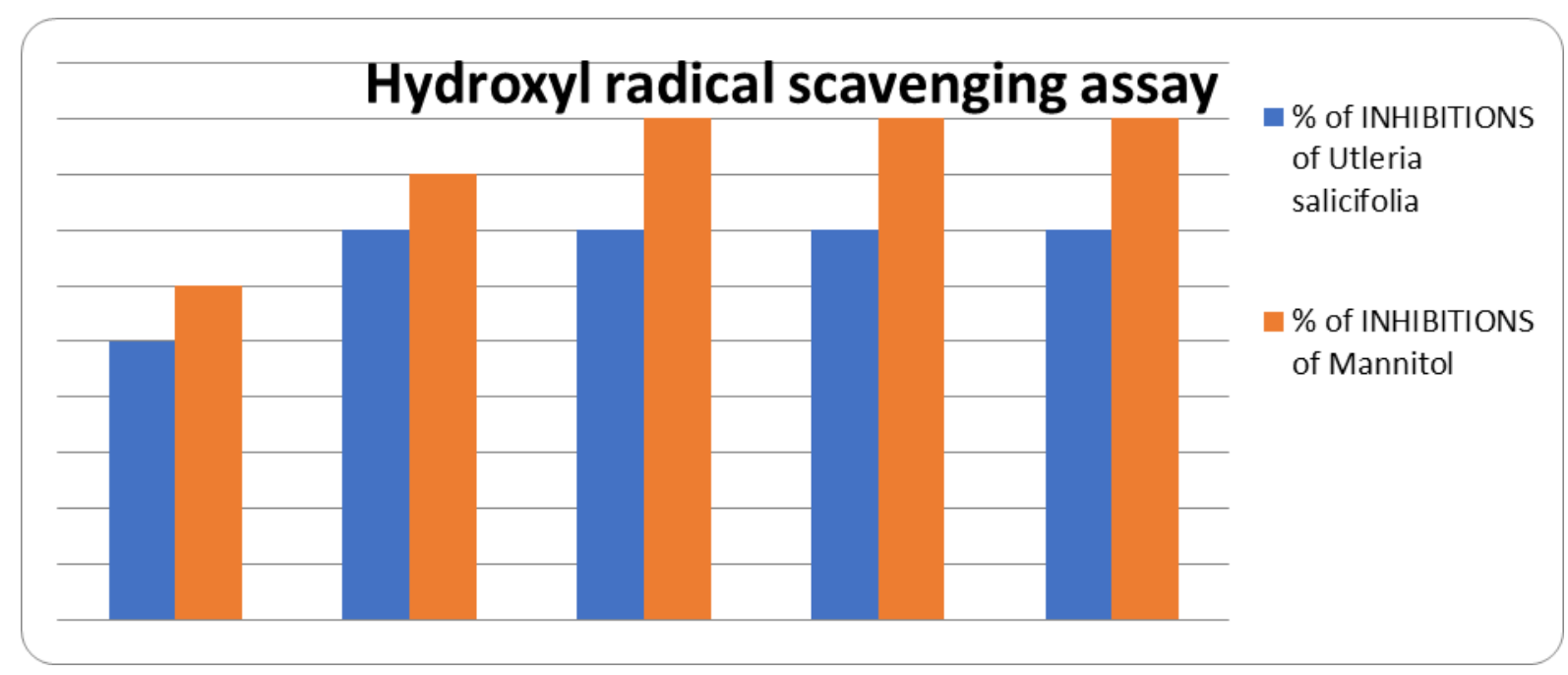

Fig.9 Gas chromatography of Utleria salicifolia leaf extract

\begin{tabular}{|c|c|}
\hline Analyzed by & :Admin \\
\hline Analyzed & $: 2 / 21 / 2017$ 1:47:05 PM \\
\hline Sample Type & : Unknown \\
\hline Level \# & $: 1$ \\
\hline Sample Name & : utleria salicifolialeaves \\
\hline Sample ID & : SAMPLE 4 \\
\hline IS Amount & $:[1]=1$ \\
\hline Sample Amount & $: 1$ \\
\hline Dilution Factor & $: 1$ \\
\hline Visl \# & $: 5$ \\
\hline Injection Volume & $: 1$ \\
\hline $\begin{array}{l}\text { Data File } \\
\text { Org Data File }\end{array}$ & $\begin{array}{l}\text { : D:IGCMS-QP2010+|Data } 2017 \text { FEB } 121-2-2017 \text { SAMPLE 4.qgd } \\
\text { : D:IGCMS-QP2010+|Data } 2017 \text { FEB } 21-2-2017 \text { SAMPLE 4.qgd }\end{array}$ \\
\hline Method File & : D:IGCMS-QP2010+|KARUNAIARMLIARML SCANggm \\
\hline $\begin{array}{l}\text { Org Method File } \\
\text { Report File }\end{array}$ & $\begin{array}{l}\text { : D:IGCMS-QP2010+|KARUNAIARMLIARML SCANggM. } \\
:\end{array}$ \\
\hline Tuning File & :C:IGCMSsolufionITUNE12017/21-02-2017.qgt \\
\hline $\begin{array}{l}\text { Modified by } \\
\text { Modified }\end{array}$ & $\begin{array}{l}\text { :Admin } \\
: 2 / 21 / 20172: 17: 05 \mathrm{PM}\end{array}$ \\
\hline
\end{tabular}

ChromatogramSAMPLE 4 D:IGCMS-QP201IData|2017FFEBL21-2-2017) (utleria salicifolia leaves.qgd

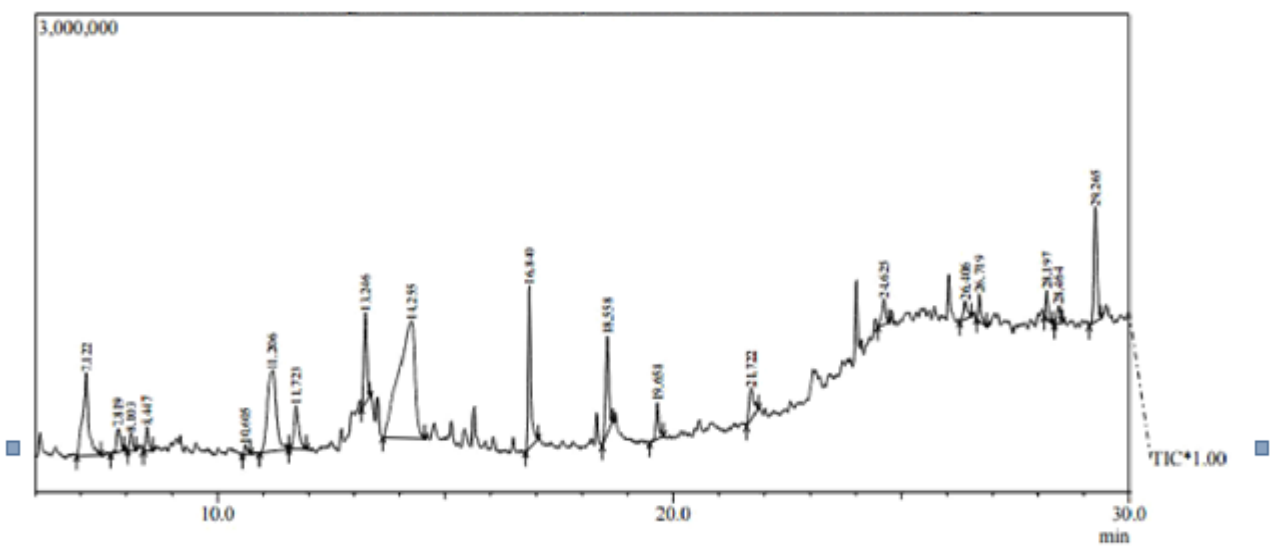




$\begin{array}{rr}\text { R.Time } & \text { I.Time } \\ 3.566 & 3.408 \\ 3.712 & 3.633 \\ 4.148 & 4.100 \\ 4.809 & 4.575 \\ 4.951 & 4.892 \\ 7.122 & 6.908 \\ 7.819 & 7.658 \\ 8.103 & 8.017 \\ 8.447 & 8.375 \\ 10.605 & 10.542 \\ 11.206 & 10.917 \\ 11.723 & 11.550 \\ 13.246 & 13.158 \\ 14.255 & 13.625 \\ 16.840 & 16.758 \\ 18.558 & 18.442 \\ 19.658 & 19.475 \\ 21.722 & 21.617 \\ 24.625 & 24.483 \\ 26.406 & 26.292 \\ 26.719 & 26.650 \\ 28.197 & 28.142 \\ 28.464 & 28.367 \\ 29.265 & 29.125\end{array}$

F.Time
3.633
3.992
4.225
4.892
5.058
7.442
7.942
8.217
8.575
10.725
11.550
11.950
13.342
14.542
17.042
18.675
19.775
21.858
24.750
26.542
26.883
28.325
28.542
29.400

Area
394816
2584233
140028
1056980
409586
4805728
797453
526556
646758
259240
7152499
2028680
2850378
18650932
4418881
3253287
1011783
1406374
1052172
672554
789040
710328
559641
3630378

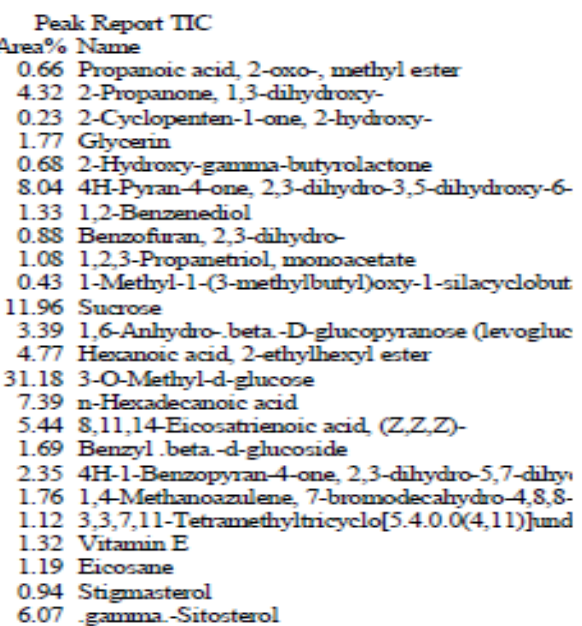

Fig.10 DPPH radical scavenging capabilities of methanol extract of Plectranthus vettiveroides leaves and standard Ascorbic acid

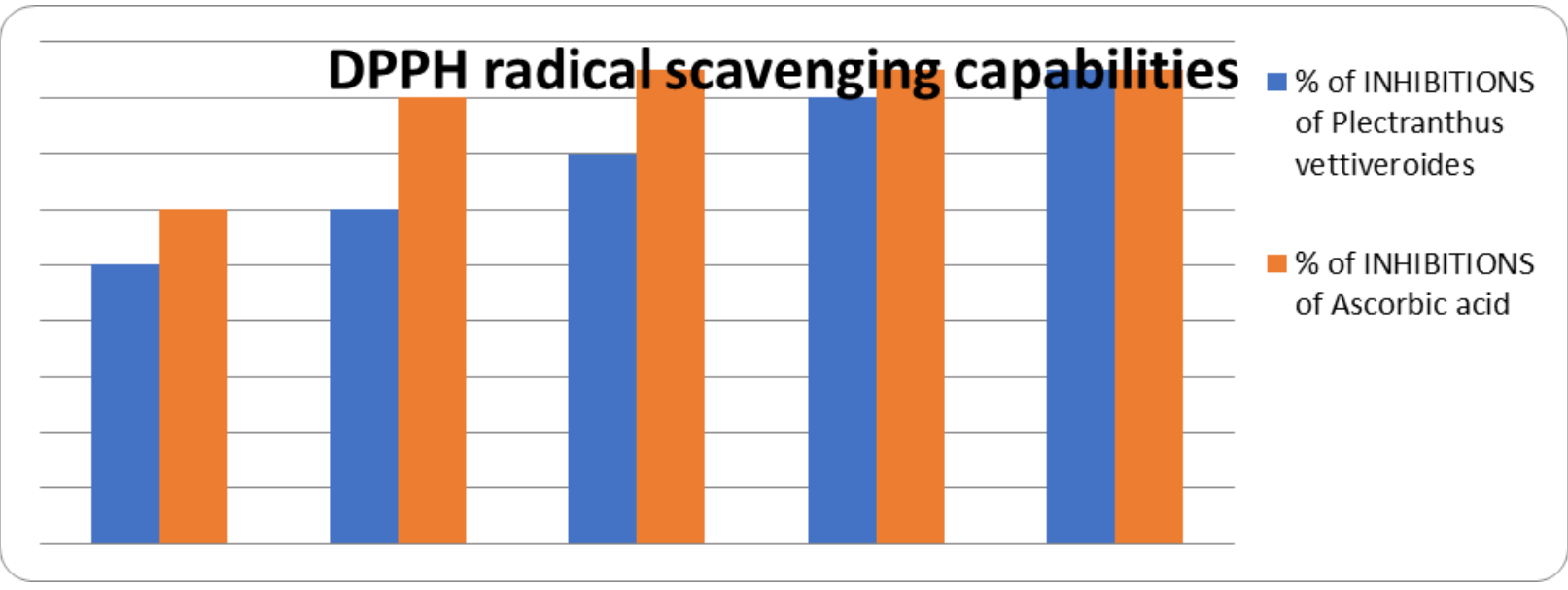

Fig.11 Metal ion chelation capabilities of methanol extract of Plectranthus vettiveroides leaves and EDTA

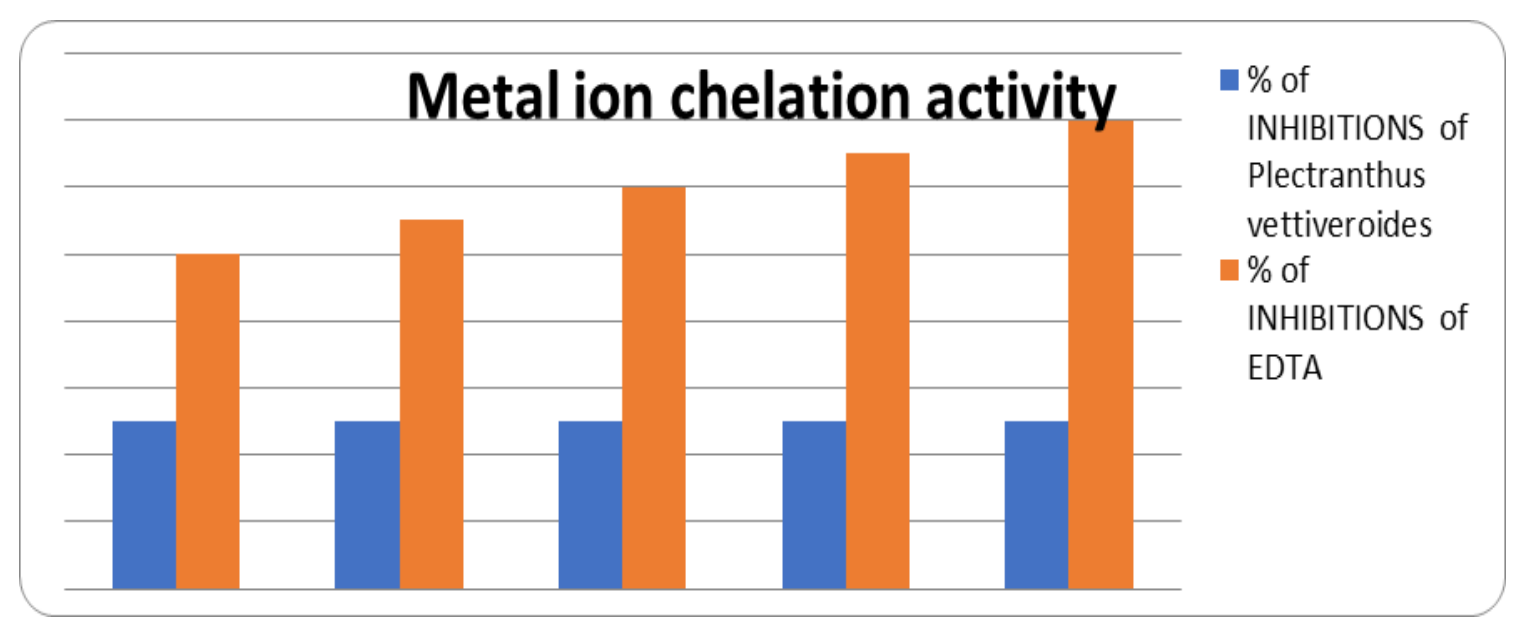


Fig.12 Superoxide radical scavenging capabilities of methanol extract of Plectranthus vettiveroides leaves and standard Ascorbic acid

\section{Superoxide radical scavenging}

$\%$ of INHIBITIONS

of Plectranthus
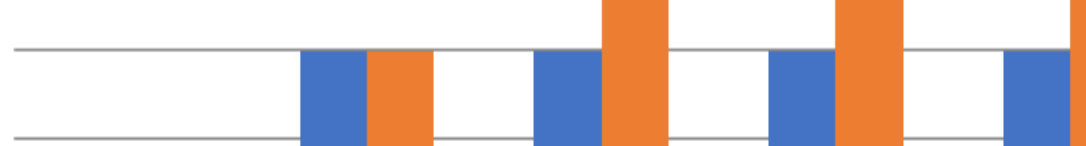

vettiveroides

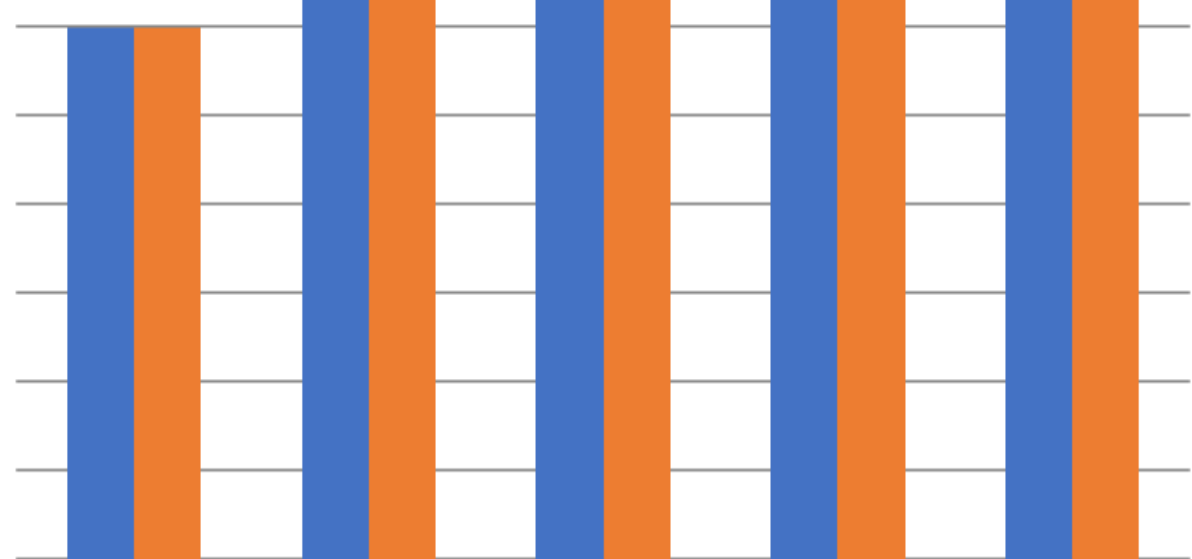

$\%$ of INHIBITIONS

of Ascorbic acid

Fig.13 Hydroxyl radical scavenging capabilities of methanol extract of Plectranthus vettiveroides leaves and Mannitol

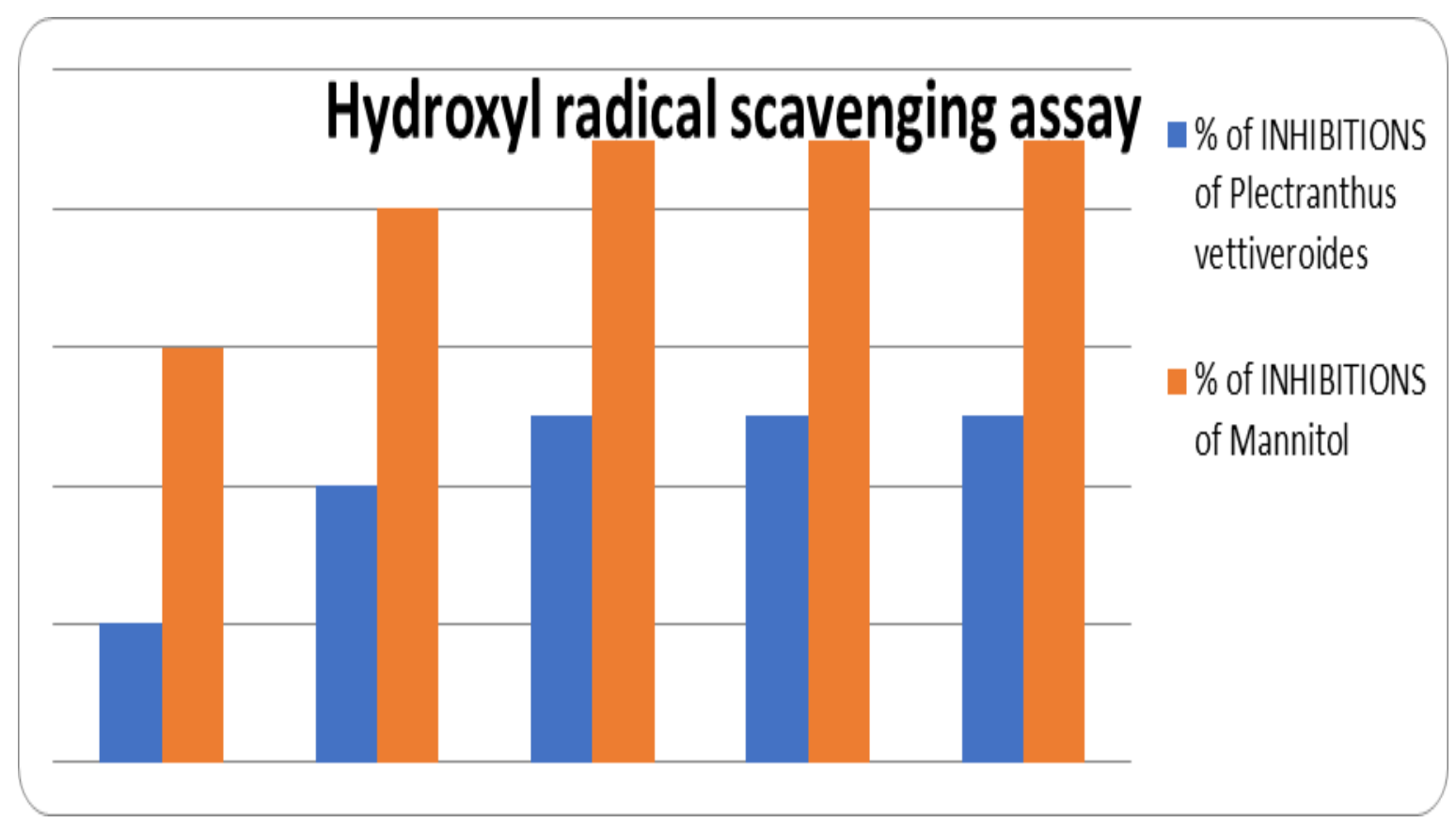


Fig.14 Gas chromatography of Plectranthus vettiveroides leaf extract

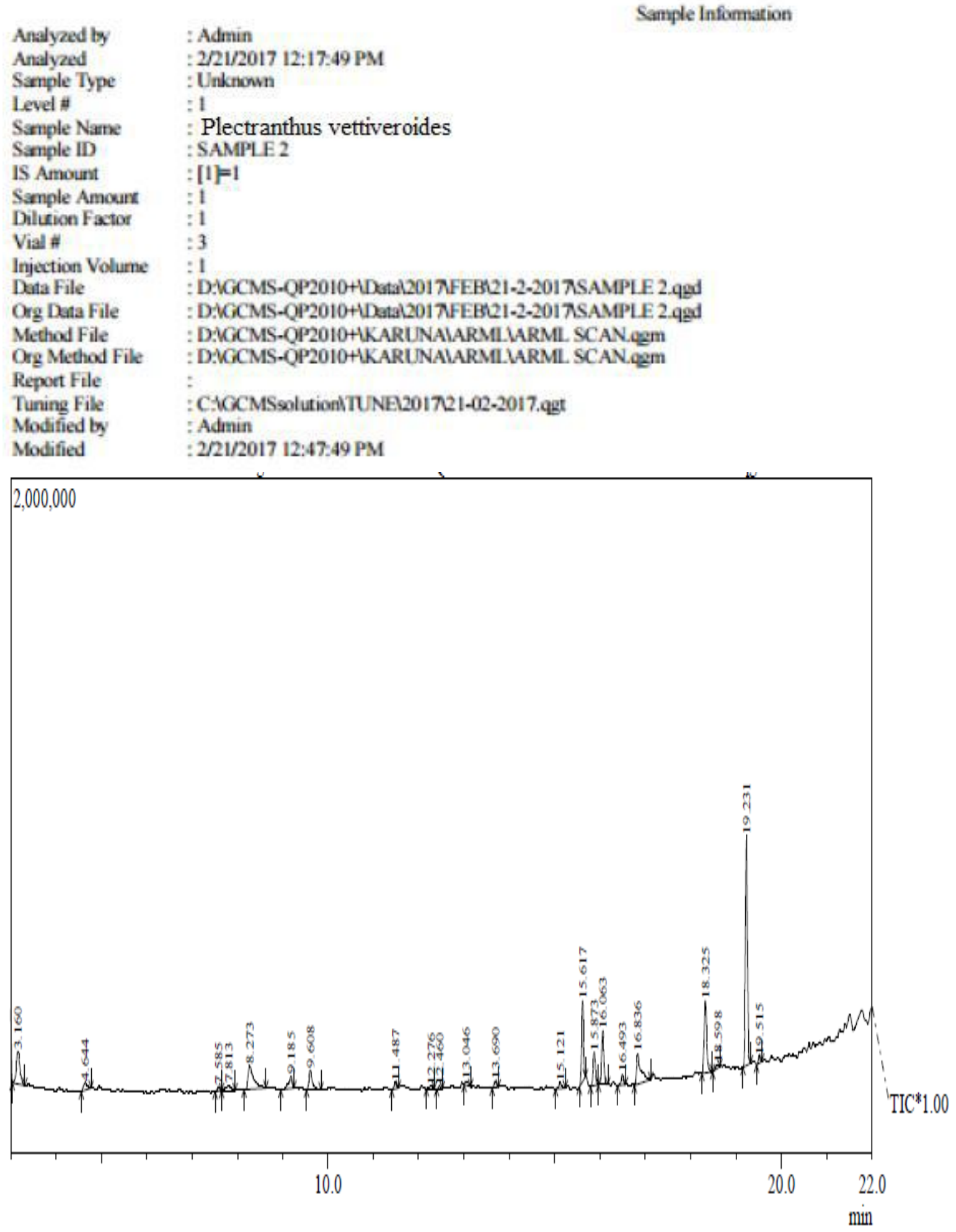




$\begin{array}{rrrrr}\text { Pesk H } & \text { R.Time } & \text { 1.Time } & \text { F.Time } & \text { Area } \\ 1 & 3.160 & 3.033 & 3.317 & 557119 \\ 2 & 4.644 & 4.558 & 4.775 & 128550 \\ 3 & 7.585 & 7.508 & 7.658 & 50931 \\ 4 & 7.813 & 7.658 & 7.950 & 116582 \\ 5 & 8.273 & 8.150 & 8.633 & 613919 \\ 6 & 9.185 & 8.958 & 9.250 & 189305 \\ 7 & 9.608 & 9.525 & 9.842 & 294639 \\ 8 & 11.487 & 11.408 & 11.550 & 65916 \\ 9 & 12.276 & 12.167 & 12.350 & 48927 \\ 10 & 12.460 & 12.400 & 12.517 & 22443 \\ 11 & 13.046 & 13.000 & 13.150 & 69134 \\ 12 & 13.690 & 13.617 & 13.758 & 71575 \\ 13 & 15.121 & 15.017 & 15.233 & 67520 \\ 14 & 15.617 & 15.550 & 15.675 & 743046 \\ 15 & 15.873 & 15.792 & 15.967 & 331603 \\ 16 & 16.063 & 15.967 & 16.175 & 554241 \\ 17 & 16.493 & 16.383 & 16.558 & 108227 \\ 18 & 16.836 & 16.758 & 17.117 & 610640 \\ 19 & 18.325 & 18.250 & 18.475 & 860663 \\ 20 & 18.598 & 18.483 & 18.642 & 55113 \\ 21 & 19.231 & 19.158 & 19.325 & 2234470 \\ 22 & 19.515 & 19.458 & 19.567 & 68515 \\ & & & & 7863078\end{array}$

\begin{tabular}{|c|c|}
\hline Peal & k Repart TIC \\
\hline Area\% & Name \\
\hline 7.09 & Furfural \\
\hline 1.63 & Propanal, 2,3-dihydroxy. \\
\hline 0.65 & 1H-Imidazo $[1,2$-b]pyraeole, 2,3-dihydro- \\
\hline 1.48 & 2-Octen-1-al, (E)- \\
\hline 7.81 & 2-Furancarboxaldetryde, 5-(thydroxymethyl)- \\
\hline 2.41 & Tridecane \\
\hline 3.75 & Phthalic arhydride \\
\hline 0.84 & Bicycho[3,2.1]oet-2-ene, 3-methy]-4-methylen \\
\hline 0.62 & Biodlethin \\
\hline 0.29 & 2(4H)-Benzofiuranone, $5,6,7,7$ a-tetrahydro-4,4, \\
\hline 0.88 & Phthalic acid, di-(1-hexen-5-yl) ester \\
\hline 0.91 & 2-Cyclohexen-1-one, 4-(3-hydroxy-1-buternyl) \\
\hline 0.86 & 7-Onabicyclo[4,1,0]heptane, 1-methyl-4-12-me \\
\hline 9.45 & $3,7,11,15$-Tetramerhyl-2-heradecen-1-ol \\
\hline 4,22 & 1. Octadecyne \\
\hline 7.05 & $3,7,11,15$-Tetramathy -2 -hexadecen-1-ol \\
\hline 1.38 & Heptacosanoic acid, methyl ester \\
\hline 7.77 & Tetradecanoic axid \\
\hline 10.95 & Phytol \\
\hline 0.70 & 2H-Pyran, 2-(2-heptadecynyloxy)tetrahydro- \\
\hline 28.42 & 1-Octadecyne \\
\hline 0.87 & 1,2-Benzenediol, 3,5-bis(1,1-dimethylethyl)- \\
\hline 100.00 & \\
\hline
\end{tabular}

Hydroxyl radical scavenging assessment of leaf extract was exhibited in table 8 and Figure 8. Maximum 35\% inhibition was achieved at $40 \mu \mathrm{g} / \mathrm{ml}$ leaf extract. Further increase in extract concentration did not affect the inhibition percentage. $60 \mu \mathrm{g} / \mathrm{ml}$ mannitol showed $45 \%$ inhibition which was the maximum.

\section{GC-MS analysis of Utleria salicifolia extract}

Figure 9 exhibits the chromatogram obtained from GC-MS analysis of Utleria salicifolia extract. Presence of essential organic component was observed while the obtained peaks were analyzed.

\section{Antioxidant activity of Plectranthus vettiveroides extract}

The study carried out on the antioxidant activity of the methanol extract from the leaves of Plectranthus vettiveroides using DPPH radical, metal chelating, hydroxyl and super oxide radical scavenging assays is described. Table 9 and Figure 10 exhibited the DPPH radical scavenging capabilities of Plectranthus vettiveroides leaf extract and ascorbic acid as well. As a standard ascorbic acid showed higher inhibition percentage as compared to leaves extract. Inhibition percentage enhances with an increase in leaf extract concentration to $100 \mu \mathrm{g} / \mathrm{ml}$ and a maximum $85 \%$ inhibition was observed at this concentration. For ascorbic acid inhibition became constant at $85 \%$ from 60 to $100 \mu \mathrm{g} / \mathrm{ml}$ concentration.

Metal ion chelating activity of leaf extract was compared to EDTA in Table 10 and Figure 11. There is no change of inhibition with respect to leaf extract concentration whereas inhibition increases with increase in EDTA content.

Assessment of Superoxide radical scavenging of leaf extract is depicted in Table 11 and Figure 12. Maximum $40 \%$ inhibition was observed at $40 \mu \mathrm{g} / \mathrm{ml}$ leaf extract whereas a constant $45 \%$ inhibition was obtained at 60 $\mu \mathrm{g} / \mathrm{ml}$ ascorbic acid content. 
Hydroxyl radical scavenging assessment of leaf extract is exhibited in table 12 and Figure 13. Maximum $20 \%$ inhibition was achieved at $40 \mu \mathrm{g} / \mathrm{ml}$ leaf extract. Further increase in extract concentration did not affect the inhibition percentage. $60 \mu \mathrm{g} / \mathrm{ml}$ mannitol showed $45 \%$ inhibition which was the maximum.

\section{GC-MS analysis of Plectranthus vettiveroides extract}

Figure 14 exhibits the Chromatogram obtained from the GC-MS analysis of Plectranthus vettiveroides leaf extract. Presence of essential organic component was observed while the obtained peaks were analyzed.

It is concluded in the current study better activity of all the three plant species was recorded. This was due to efficient extraction of phytochemicals. The extracts from three different plant leaves showed antioxidant activity which was substantiated by four different assay methods. Further Gas Chromatography analysis verified the presence of important compound in the plant extracts. Further study can be carried out on isolating a specific bioactive compound with commercial value. Being a rich source of antioxidant, these medicinally important plants have values as functional ingredients in food industry.

\section{References}

Djeridane, A., Yousfi, M., Nadjemi, B., Boutassouna, D., Stocker, P., Vidal, N. 2006. Antioxidant activity of some Algerian medicinal plant extracts containing phenolic compounds. Food Chem. 97, 654-60.

Gocer, H., Gulcin, I., 2011. Caffeic acid phenethyl ester (CAPE): correlation of structure and antioxidant properties. Int
J Food Sci Nutr. 62, 821-5.

Gulcin, I., 2012. Antioxidant activity of food constituents: an overview. Arch Toxicol. 86, 345-91.

Halliwell, B., Gutteridge, J.M.C., 1981. Formation of thiobarbituric acid reactive substances from deoxyribose in the presence of iron salts: the role of superoxide and hydroxyl radicals. FEBS Lett. 128, 347-52.

Harman D: Free radical theory of aging. Current status. 1998, Amster-dam: Elsevier, p. 3-7

Ilavarasan, R., Mallika, M., Venkataraman, S. 2005, Anti-inflammation and antioxidant activities of Cassia fistula Linn. bark extracts. Afr J Trad Compl Altern Med. 2, 70-85.

Karimi, E., Jaafar, H.Z.E. 2011, HPLC and GC-MS determination of bioactive compounds in microwave obtained extracts of three varieties of Labisia pumila benth. Molecules. 16, 6791-805.

Mu, Y.M., Yanass, T., et al., 2001. Saturated FFAs, palmitic acid and stearic acid, induced apoptosis in human granulose cells. J Endocrinol. 142, 3590-97.

Nunes, P.X., Silva, S.F., Guedes, R.J., Almeida, S. 2012. Biological oxidations and antioxidant activity of natural products, Phytochemicals as nutraceuticals - Global Approaches to Their Role in Nutrition and Health.

Oluyemi, K.A., Okwuonu. U.C., Baxter, D.G., Oyesola, T.O. 2007, Toxic effects of methanolic extract of Aspilia africana leaf on the estrous cycle and uterine tissues of Wistar rats. Int $\mathbf{J}$ Morphol. 25, 609-14.

Prasad, M.P., 2014. Invitro Phytochemical Analysis and Anti-oxidant studies of Hibiscus species. International Journal of Pure and Applied Biosciences. 2(3), 83-8.

Ruch. R.J., Cheng. S-J, Klaunig, J.E. 1989 Prevention of cytotoxicity and 
inhibition of intercellular communication by antioxidant catechins isolated from Chinese green tea. Carcinogenesis. 10, 1003-8.

Uma, B., Prabhakar, K., Rajendran, S., Sarayu, L.Y. 2009. Studies on GC/MS spectroscopic analysis of some bioactive antimicrobial compounds from Cinnamomum zeylanicum. J Med Plants. 8(31), 125-31.

Vongtau, H.O., Abbah, J., Chindo, B.A., Mosugu, O., Salawu, A.O., Kwanashie, H.O., Gamaniel, K.S., 2005. Central inhibitory effects of the methanol extract of Neorautanenia mitis root in rats and mice. J Pharm Biol. 43, 113120.

Wannes, W.A., Mhamdi, B., Sriti, J., Jemia,
M.B., Ouchikh, O., Hamdaoui, G., Kchouk, M.E., Marzouk, B. 2010, Antioxidant activities of the essential oil and methanol extracts from myrtle (Myrtus communis var. italica L.) leaf, stem and flower. Food Chem Toxicol. 48, 1362-70.

Zengin, G., Cakmak, Y.S., Guler, G.O., Aktumsek, A. 2011. Antioxidant properties of methanolic extract and fatty acid composition of Centaurea urvillei DC. subsp. hayekiana Wagenitz. Rec Nat Prod. 5, 123-32.

Zhang, Q.X., Wang, Q.L., Han, J.H. 1995. Effect of fatty oil in Periploca sepium on neural system in mice. Xi'an Med Univ. 16, 43-4.

\section{How to cite this article:}

Sumangala, N., M. Jayaramu and Prasad, M.P. 2019. Antioxidant Studies and GCMS Analysis of the Phytochemical Compounds of Some Endangered Plant Species Collected from the Western Ghats. Int.J.Curr.Microbiol.App.Sci. 8(06): 3338-3354. doi: https://doi.org/10.20546/ijcmas.2019.806.397 